\title{
The Nursing Implementation of Monitoring Blood Glucose in Increasing the Stability of BloodGlucose Level in Patients with Diabetes Mellitus
}

\author{
$1^{\text {st }}$ Abdul Gani \\ Nursing Department \\ Poltekkes Kemenkes Palembang \\ Palembang, Indonesia \\ abdulgani146@gmail.com
}

\author{
$2^{\text {nd }}$ Ira Kusumawaty \\ Nursing Department \\ Poltekkes Kemenkes Palembang \\ Palembang, Indonesia \\ irakusumawaty@poltekkespalembang.ac.id
}

\author{
$3^{\text {rd }}$ Sherli Shobur \\ Nursing Department \\ Poltekkes Kemenkes Palembang \\ Palembang, Indonesia \\ sherlishobur@gmail.com
}

\author{
$4^{\text {th }}$ Marisa Kartika Putri \\ Nursing Department \\ Poltekkes Kemenkes Palembang \\ Palembang, Indonesia \\ marisa.kartikap25@gmail.com
}

Corresponding author: abdulgani146@gmail.com

\begin{abstract}
Diabetes Mellitus is characterized by an increase in blood sugar level and this condition is treated by giving insulin injections. Overdose of insulin will cause hypoglycemia hence it's important to independently check blood glucose levels. This research aims to obtain an overview of the implementation of a self-monitoring of blood glucose level in Diabetes Mellitus patients. The method used in this research is a narrative study of literature and the required criteria for used literature consists of 5 articles or research results published online in the year 2015-2019 and available in full text for researches as data to be analyzed. Results of data analysis show that the stability of blood glucose levels can be achieved by selfmonitoring of blood glucose. Self-monitoring of blood glucose increase the stability of blood glucose levels in the form of blood glucose values in the normal range and reduce HbA1c level. The implementation of SelfMonitoring of blood glucose has variation in the procedures, hence a deeper study about the method of self- monitoring of blood glucose is mandatory to increase the stability of blood glucose levels.
\end{abstract}

Keywords: Diabetes Mellitus, Self-monitoring of blood glucose, blood glucose level, and the stability of blood glucose level.

\section{INTRODUCTION}

Diabetes mellitus according is a group of metabolic disorders due to impaired insulin secretion, insulin performance, or both, which is characterized by an increase in blood glucose levels (hyperglycemia). Longterm hyperglycemia can play a role in the development of chronic microvascular complications (kidney and eye disease) and neuropathic complications. Diabetes is also associated with an increased incidence of macrovascular diseases, such as coronary artery disease (myocardial infarction), cerebrovascular disease (stroke), and peripheral vascular disease [1]. Globally, diabetes patients have increased rapidly where in 1980 it was estimated to reach 108 million to 422 million adults living with diabetes in 2014 , or about four times as much [2]. According to [3]

shows that the prevalence of diabetes mellitus sufferers based on doctor's diagnosis in people aged $\geq$ 15 years is $2 \%$. Based on the age category, the age ranges with the largest DM sufferers were 55-64 years and 65-74 years. In addition, there are more women with Diabetes Mellitus in Indonesia (1.8\%) than men $(1.2 \%)$. Then for domicile areas there are more Diabetes Mellitus sufferers in urban areas (1.9\%) compared to rural areas (1.0\%). Diabetes Mellitus in South Sumatra Province is also experiencing enhancement. This can be seen in the results of the 2013 Riskesdas, the prevalence of Diabetes Mellitus based on a doctor's diagnosis in people aged $\geq 15$ years in 2013, namely $0.9 \%$ [4]. Then the results of the 2018 Riskesdas increased to $1.4 \% .3$ The number of Diabetes Mellitus sufferers in Palembang is 4904 people. Consisting of 2035 male sufferers and 2869 female sufferers [5]. The manifestation of this condition is elevated blood glucose levels (hyperglycemia) and glucosuria. The treatment for this condition is giving insulin injections. Insulin injections will lower blood glucose levels, where the use and storage of glucose in the muscles and liver will be 
increased. However, overdosing on insulin will cause hypoglycemia, which will lead to seizures and even death [6]. Therefore, it is highly recommended for patients with diabetes mellitus to monitor their levels of blood glucose so that patients can know the ups and downs of blood glucose levels, including if complications arise early hypoglycemic[7]. One of the factors that determine a person's health behavior is the level of knowledge [8]. In the process of treating Diabetes Mellitus, patients and families need to increase participation in DM management efforts in order to achieve better results [9]. Diabetes Mellitus patients need to get information including basic knowledge about diabetes, independent monitoring, causes of high blood glucose levels, oral hypoglycemia drugs, physical activity, signs of hypoglycemia and complications [10].

\section{METHOD}

This research is a case study that describes the implementation of nursing to monitor blood glucose levels in increasing the stability of blood glucose levels in patients with diabetes mellitus. The criteria for the articles or research results used in this study consisted of 5 articles or research results published online between 2015-2019. The articles or research results are available in full text for the researcher to use as data for analysis. The articles and research results used in this study were obtained through exploration of the Google Scholar source for 5 articles. Research data analysis was carried out by researchers by presenting 5 research articles that have relevance to the topic or research problem. The next step is the researcher analyzes the article by integrating research results, connecting related topics,. identifying the main issues / research results relevant to the research study.

The results of the above research indicate that after being given the implementation of blood glucose level monitoring and health education about Diabetes Mellitus, the client's blood glucose level is in the normal range (80-100 $\mathrm{mg} / \mathrm{dL}$ ) and the family becomes more aware to participate in maintaining the client's health. According to Ariyani (2019), it was found that the value of blood sugar levels for Diabetes Mellitus sufferers was in the normal range after five days of implementation, namely measuring blood sugar levels providing health education regarding foot care and diabetic foot exercise. The implementation of monitoring blood glucose levels discussed in this study has relevance to the five studies presented in the table above. Monitoring of blood glucose levels showed significant changes in the risk of instability in. The article source is google scholar.

\begin{tabular}{lllll}
$\begin{array}{l}\text { Researcher } \\
\text { and Research } \\
\text { Title }\end{array}$ & $\begin{array}{l}\text { Research } \\
\text { Purposes }\end{array}$ & Design & Sample & Results \\
\hline
\end{tabular}

Ariyani, Nadha (2019) [12]

Family Nursing Care for Diabetes Mellitus in the Work Area of Puskesmas Sempaja Samarinda

Knowing family nursing care with Diabetes Mellitus

Descriptive research in the form of case study
Two families with Diabetes Mellitus in the working area of Puskesmas Sempaja Samarinda, namely Mrs. N and Mrs. S
The assessment found that the blood sugar level on both patients, Mrs. N and Mrs. S are higher than normal. Mrs. N said that she never checked her blood sugar while at home. Mrs. S only occasionally checks his blood sugar at home. Through the assessment, a nursing diagnosis was obtained. Risk of instability in blood sugar levels associated with the inability of the family to care for family members who were sick with Diabetes Mellitus in both subjects. Nursing problems risk of instability resolved by measure the client's blood sugar level, explain to the client about the Diabetes Mellitus diet and how to treat Diabetes Mellitus at home, and recommend to routine control at the Puskesmas. 


$\begin{array}{ll}\begin{array}{l}\text { Hidayah, Chusnaeny } \\ \text { (2017) }\end{array} & \begin{array}{l}\text { To do family } \\ \text { nursing care } \\ \text { f14] }\end{array} \\ \begin{array}{l}\text { for family Nursing } \\ \text { Care with Diabetes }\end{array} & \text { members with } \\ \text { Mellitus on Dusun } & \\ \text { Wonokerto, } & \\ \text { Sumberwono } & \\ \text { Village, Bangsal } & \\ \text { District, Mojokerto } & \\ \text { Regency }\end{array}$

\section{Case study Two families} with Diabetes Mellitus in Dusun Wonokerto. (wil be focused on subject 2 who experience problemsatrisk of instability of blood glucose levels)
Subject 2 (Mr.K) has been suffering from Diabetes Mellitus since 2 years ago, and thinks that his blood sugar drops during fasting so that it does not maintain his diet and Mrs. K's family provides sweet food and drinks so that Mrs. K's blood sugar level is increasing. The nursing diagnosis obtained is the risk of instability of blood glucose levels associated with the family's inability to modify the environment that affects Diabetes Mellitus. The interventions given during five visits were to provide information about diabetes mellitus diabetes, teach diabetic foot exercises, encourage clients to be diligent in exercising, and suggest routine blood glucose control at the hospital or health center. The intervention was carried out in 5 visits for 12 days with the results of the evaluation showing that the family understood what had been taught.

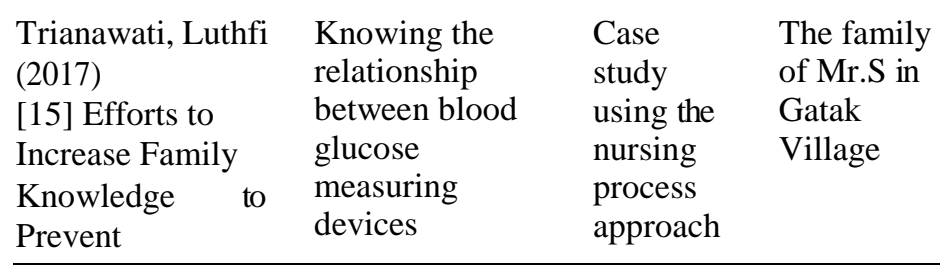

\begin{abstract}
Mr. S has felt the symptoms of Diabetes Mellitus since 1 year ago but after feeling better, Mr. S became tired of taking medication and ignored his diet, did not regularly check his blood sugar and often consumed sweet and high-fat foods such as fried. From the results of
\end{abstract}

\section{RESULT AND DISCUSSION}

The discussion of this study is focused on the results of research from five (5) articles which found that the stability of blood glucose levels in type 2 DM patients can be achieved by monitoring independent blood glucose levels or SMBG. Complications of type 2 diabetes include hypoglycemia (blood glucose levels $<50 \mathrm{mg} \mathrm{/} \mathrm{dl)} \mathrm{and} \mathrm{hyperglycemia} \mathrm{(blood} \mathrm{glucose}$ levels $>200 \mathrm{mg} / \mathrm{dl}$ ) so that type 2 diabetes mellitus patients are advised to monitor their blood glucose levels independently. This will greatly help patients to be able to find out their blood glucose levels at any time so that patients know the fluctuations in blood glucose levels, including when hypoglycemic complications arise early [15]. This is in line with [16] case study research entitled Family Nursing Care with Diabetes Mellitus in the Work Area Of the Sempaja Puskesmas, Samarinda) " which carried out the implementation of blood sugar monitoring and health education for 5 days of implementation and succeeded in knowing the occurrence of hypoglycemia (GDS: $60 \mathrm{mg} / \mathrm{dL}$ ) on the fourth day and blood glucose levels stabilized on the fifth and sixth days, namely $159 \mathrm{mg} / \mathrm{dL}$ and 151 $\mathrm{mg} / \mathrm{Dl}$ [16].

In addition, the nursing care conducted by [12] entitled Efforts to Increase Family Knowledge to Prevent the Risk of Hypoglycemia in Mr.S in Gatak Village [11] shows that before implementation, Mr. S. was tired of taking medication and neglecting his diet, the family also did not pay attention his diet, and rarely check his blood glucose level. However, after implementing blood sugar checks and gave family health education, the family is excited to control Mr. S's nutritional intake to prevent blood sugar levels from rising and encourage Mr.S to regularly check his blood sugar level. Intensive monitoring of blood glucose also has a positive impact on glycemic control both in the short and long term in insulin- treated type $2 \mathrm{DM}$ patients. SMBG done at least 2 times a day can cause a significant decrease in $\mathrm{HbA} 1 \mathrm{c}$ of up to $-1.2 \%$. [14].

\section{CONCLUSION}

There are 5 (five) articles that have relevance to the implementation of monitoring blood glucose levels in increasing the stability of blood glucose levels. Monitor blood glucose levels can increase the stability of blood glucose levels in Diabetes Mellitus sufferers. Action is carried out by educating the client about the causes of increased blood glucose levels and checking blood sugar according to the procedure. The implementation of the blood glucose level monitor implemented in the article has variations in implementation, so a study of the standard blood glucose level monitoring method is needed to increase the stability of blood glucose levels. Researchers recommend to routinely check blood sugar while (GDS) once a day. 


\section{ACKNOWLEDGMENT}

The author is grateful to the Polytechnic Ministry of Health Palembang for supporting this research.

\section{REFERENCES}

[1] Suddarth B. Buku Ajar Keperawatan Medikal Bedah Edisi 8 Volume 2. 2013.

[2] Report Wg. Hari Diabetes Sedunia 2018. Jakarta Selatan, Indonesia: Pusat Data Dan Informasi Kementrian Kesehatan Ri 2016.

[3] Kementerian Kesehatan Ri Badan Penelitian Dan Pengembangan. Hasil Utama Riset Kesehatan Dasar. Kementrian Kesehat Republik Indones 2018:1-100.

[4] Riskesdas. Hari Diabetes Sedunia Tahun 2018. Pus Data Dan Inf Kementrian Kesehat Ri 2019:1-8.

[5] Pemerintah Kota Palembang. Profil Kesehatan Kota Palembang Tahun 2011 2012:1-73.

[6] Bender D. Pemantauan Penderita Diabetes Mellitus. Bagian Biokimia Fakultas Kedokteran Universitas Wijaya Kusuma Surabaya: Jurnal Ilmiah Kedokteran Volume 2 Edisi Oktober 2014. J Ilm Kedokt Wijaya Kusuma 2014;2:88-97.

[7] (Ada) Ada. Medical Advice For People With Diabetes In Emergency Situations.American Diabetes Association Journal 2012.

[8] Perdana Aa, Ichsan B, Rosyidah Du. Hubungan Tingkat Pengetahuan Tentang Penyakit Dm Dengan Pengendalian Kadar Glukosa Darah Pada Pasien Dm Tipe Ii Di Rsu Pku Muhammadiyah Surakarta.

[9] Biomedika 2013;5:17-21.

[10] Https://Doi.Org/10.23917/Biomedika.V5i2.265.

[11] Soelistijo Sa, Lindarto D, Decroli E, Permana H, Sucipto Kw, Kusnadi Y, Et Al. Pedoman Pengelolaan Dan Pencegahan Diabetes Melitus Tipe 2 Dewasa Di Indonesia 2019. Perkumpulan Endokrinol Indones 2019:1- 117.

[12] Putri N, Isfandiari M. Hubungan Empat Pilar Pengendalian Dm Tipe 2 Dengan Rerata Kadar Gula Darah. J Berk Epidemiol 2013;1:234-43.

[13] Hidayah C. Asuhan Keperawatan Keluarga Dengan Diabetes Mellitus Dusun Wonokerto Desa Sumberwono Kecamatan Bangsal Kabupaten Mojokerto. J Chem Inf Model 2019;53:1689-99.

[14] Trianawati L. Upaya Peningkatan Pengetahuan Keluarga Untuk Mencegah Risiko Hiperglikemia Pada Tn.S Di Desa Gatak 2017.

[15] Dewi R. Hubugan Antara Pemantauan Glukosa Darah Mandiri Dengan Hipoglikemia Pada Diabetes Mellitus Tipe 2 Di Puskesmas Kebun Jeruk. Indian J Nat Sci 2016;1:92-6.

[16] Ugwu E, Gezawa I, Adeleye O. Glycemic Impact Of Intensified Self Monitoring Of Blood Glucose In Insulin Treated Subjects With Type 2 Diabetes Mellitus. J Soc Heal Diabetes 2018;06:027- 33. Https://Doi.Org/10.1055/S-00381676194.

[17] Masharani U. Pemantauan Penderita Diabetes Mellitus. Bagian Biokimia Fakultas Kedokteran Universitas Wijaya Kusuma Surabaya: Jurnal Ilmiah Kedokteran Volume 2 Edisi Oktober 2014. J Chem Inf Model 2014;53:1689-99.
[18] Ariyani N. Asuhan Keperawatan Dengan Diabetes Mellitus Di Wilayah Kerja Puskesmas Sempaja Samarinda. Program Diii Keperawatan Poltekkes Kemenkes Kaltim 2019. 